\title{
Tsunami flood risk prediction using a neural network
}

\author{
H. Gotoh \& M. Takezawa \\ Nihon University, Tokyo, Japan
}

\begin{abstract}
The 2011 earthquake off the Pacific coast of Tohoku (known as the "Sendai Earthquake") occurred on March 11, 2011 and severely damaged the Tohoku coastal area facing the Pacific Ocean. The number of casualties in the Sendai earthquake, as of August 9, 2013, included 15,883 deaths, with 2656 people still missing. The cause of death for nearly $90 \%$ of those killed was drowning because many people were swept away by the resulting tsunami. Focusing on the area inundated by the current induced by the tsunami, even in adjacent areas, a difference was apparent in the inundation distances from the coastline. Clarification of the reason for this difference is necessary for city planning when considering disaster reduction in the future.

In this study, we first clarify the factors that promote inundation in the Sendai area, excluding the effects from small ground undulations, by using a neural network that has been used to solve a complex relationship with each of the factors. Based on the results of the factors that promote inundation, we have selected Iwata City in the Shizuoka Prefecture as a study area because its region is similar to the Sendai area that has flat level ground and also it is likely to be struck by a tsunami generated from any Tokai, Tounankai, and Nankai type earthquake. In our risk prediction, we estimate the risk for tsunami damage in Iwata City and propose measures to reduce this damage.

Keywords: tsunami, neural network, "inundation factors", risk analysis.
\end{abstract}

\section{Introduction}

The Great East Japan Earthquake occurred on March 11, 2011, and the coastal zones along the Pacific Ocean in the Tohoku area were inundated by the current induced by the resulting tsunami. There was extensive damage and loss of life in 
an instant; however, a difference was seen in the inundation area away from the coastline. In cases of extreme inundation in the Sendai plain, inland areas $5 \mathrm{~km}$ from the coastline were flooded. Although it is assumed that objects along the coastline, including houses, roads, rivers, cultivated land and coastal forestation inhibited the tsunami-induced current, the effect of these objects on inhibiting this current has yet to be clarified.

In this study, based on the damage after the Great East Japan Earthquake, the factors that inhibit or promote inundation from tsunami-induced currents were investigated using a neural network. From the results, we estimate the potential damage caused by a tsunami from the Tokai earthquake, which is predicted to occur in the near future.

\section{Damage from tsunami due to the Great East Japan Earthquake}

The Tohoku area along the coast facing the Pacific Ocean was severely damaged by the tsunami caused by the Great East Japan Earthquake. The wave height of the tsunami was reported to be between 2 and $21 \mathrm{~m}$ based on field investigations by numerous researchers [2]. Moreover, as shown in Figure 1, the value of the maximum run-up height was reported to reach nearly $40 \mathrm{~m}$ [2]. Approximately $90 \%$ of the casualties from the Great East Japan Earthquake were a result of the tsunami [3]. Figure 2 shows examples of damage caused by the tsunami.
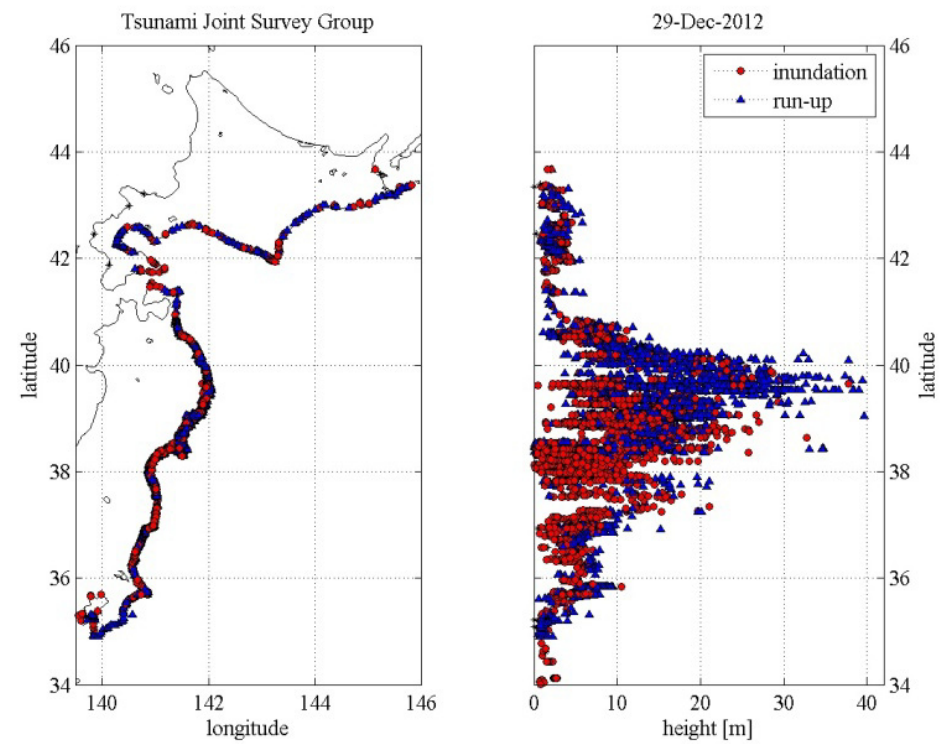

Figure 1: Tsunami wave height and run-up height measured by the 2011 Tohoku Earthquake Tsunami Joint Survey (TTJS) Group [3]. 


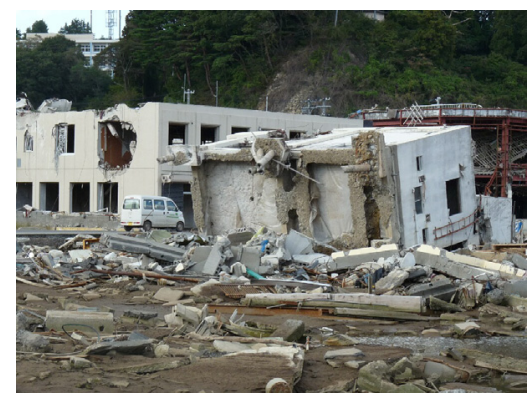

(a) Damaged building in Onagawa City

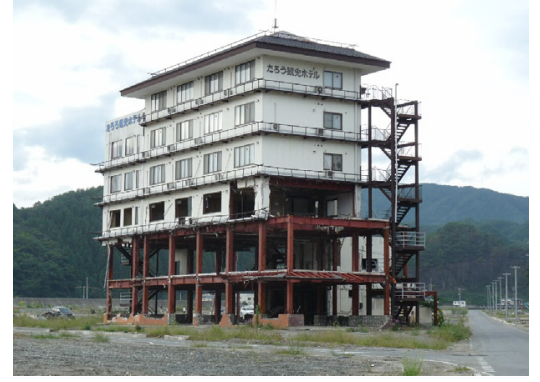

(c) Damaged hotel in Taro City

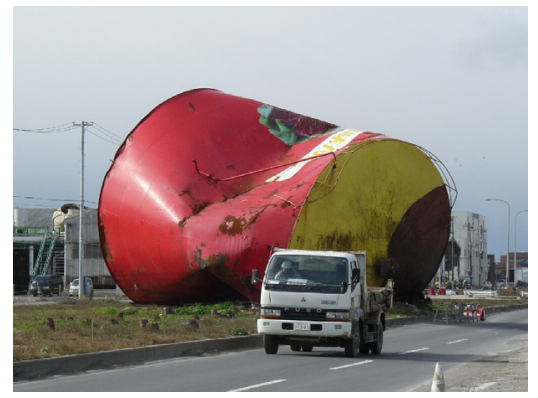

(b) Flotsam in Ishinomaki City

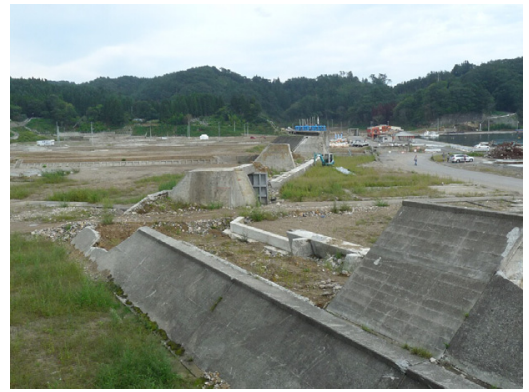

(d) Collapsed dike in Taro City

Figure 2: $\quad$ Examples of damage caused by the tsunami.

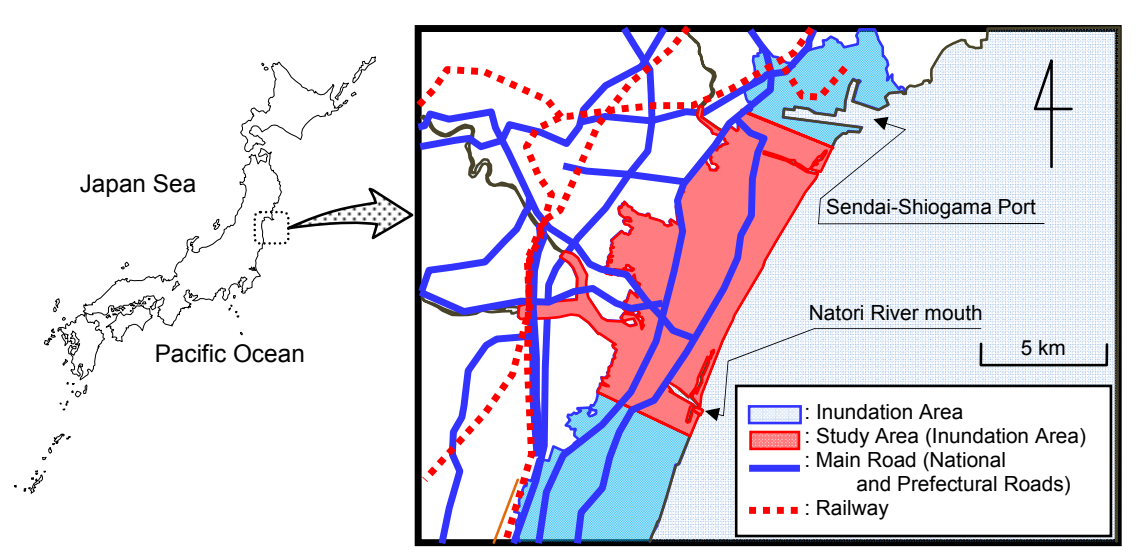

Figure 3: $\quad$ Map of the study area (Sendai plain). 
Figure 3 shows the area in the Sendai plain inundated by the tsunami-induced current. The maximum distance of the inundation area from the coastline was reported to be approximately $5 \mathrm{~km}$. However, as shown in Figure 3, there is a difference in the distances of the inundation area from the coastline, even if the area is primarily flat. It is assumed that the inundation area is affected by objects on the ground (predictor variables).

\section{Methodology}

\subsection{Estimation of factors that promote inundation}

To investigate the effect of predictor variables, we selected a flat area of land the Sendai plain. As shown in Figure 4, 60 survey lines perpendicular to the coastline were set up at $200 \mathrm{~m}$ intervals. Along each survey line, the width of the beach, the width of coastal forestation, the width of fields including the ground (e.g., cultivated land), roads and parks, the width of big buildings such as factories and warehouses, the width of residential areas, the width of rivers perpendicular to the coastline, the width of rivers parallel to the coastline, the width of lakes and ponds, and the wave height were selected as predictor

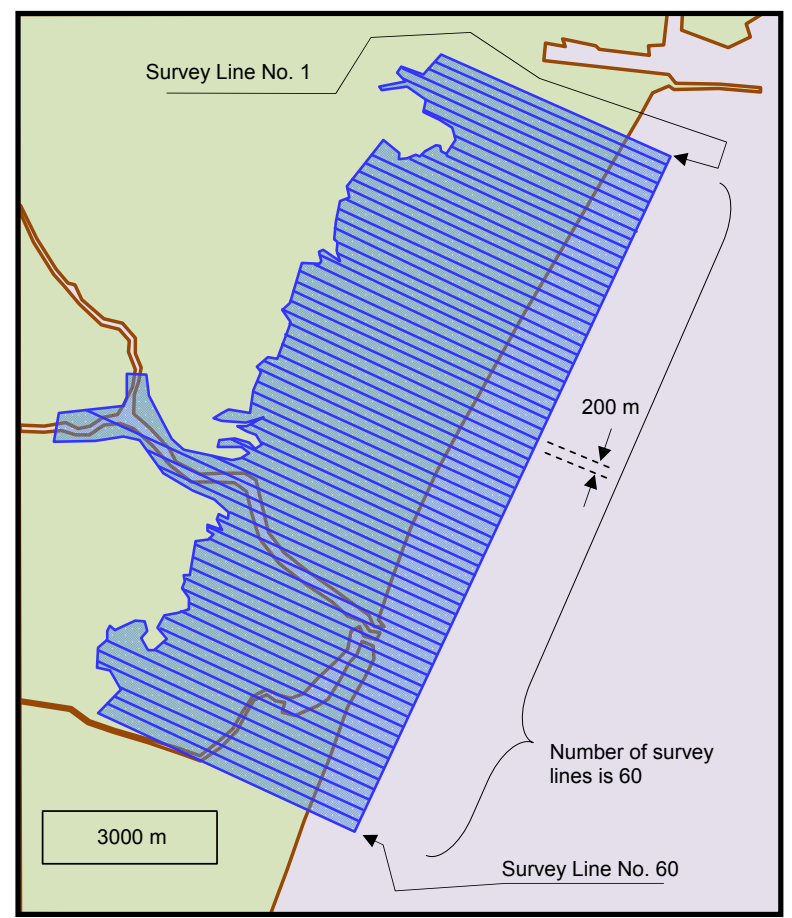

Figure 4: $\quad$ Survey lines in study area. 


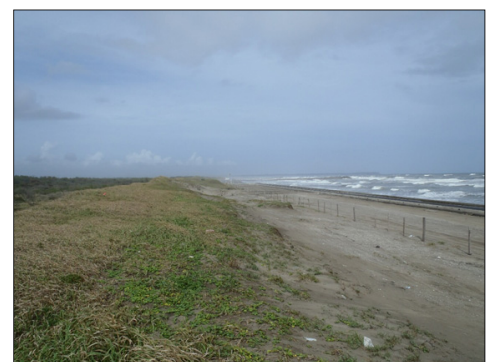

(a) Beach

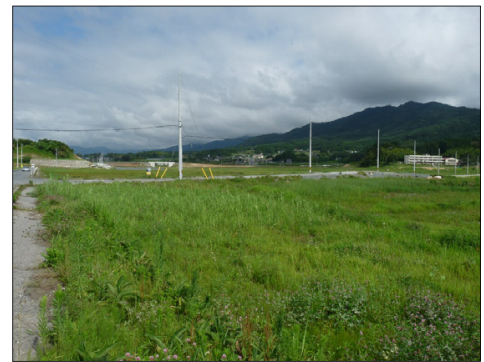

(c) Field (cultivated land)

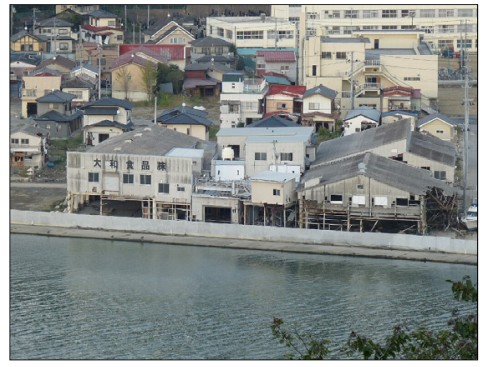

(e) Residential area

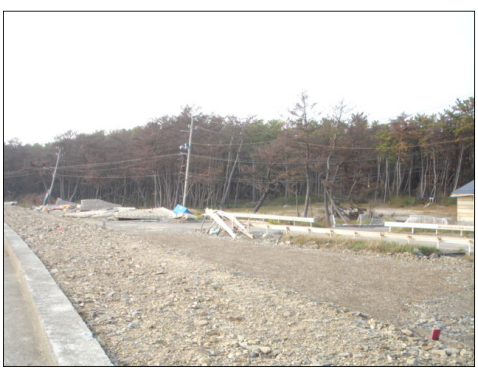

(b) Coastal forestation

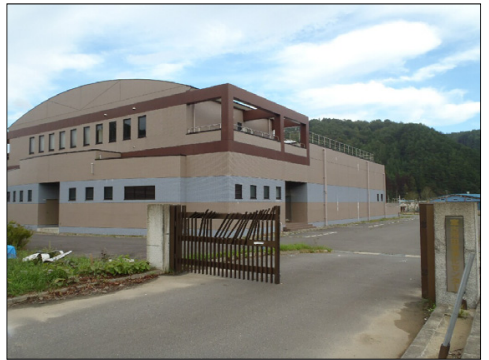

(d) Big building

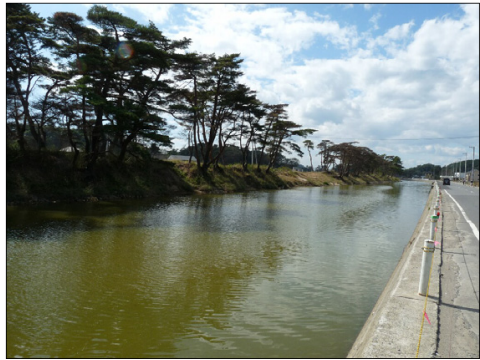

(f) River (canal)

Figure 5: $\quad$ Examples of predictor variables.

variables to perform the analysis using a neural network. Figure 5 shows examples of these objects. As shown in Figure 6, "the rivers perpendicular to the coastline" were defined as ranging from 0 to $45^{\circ}$ from the survey line, and "the rivers parallel to the coastline" were defined as ranging from 46 to $90^{\circ}$ from the survey line. The values of the predictor variables were measured as length across the survey line, and the values of the objective variable were equal to the inundation distance from the coastline along the survey line, as shown in Figure 7. The degrees of importance of the predictor variables (the factors that promote inundation) against the objective variable were estimated a using neural network. A neural network is a computational model based on the structure and functions of biological neural networks. Information that flows through the network affects the structure of the neural network because it changes, or learns, based on inputs 
and outputs. Neural networks are considered nonlinear statistical data modeling tools where the complex relationships between inputs and outputs are modeled or patterns are found. Here, we used an IBM software package, SPSS Neural Networks V 20, to create the hierarchical neural network.

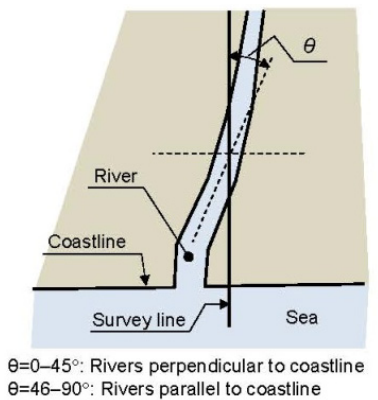

Figure 6: Definition of rivers perpendicular or parallel to the coastline.

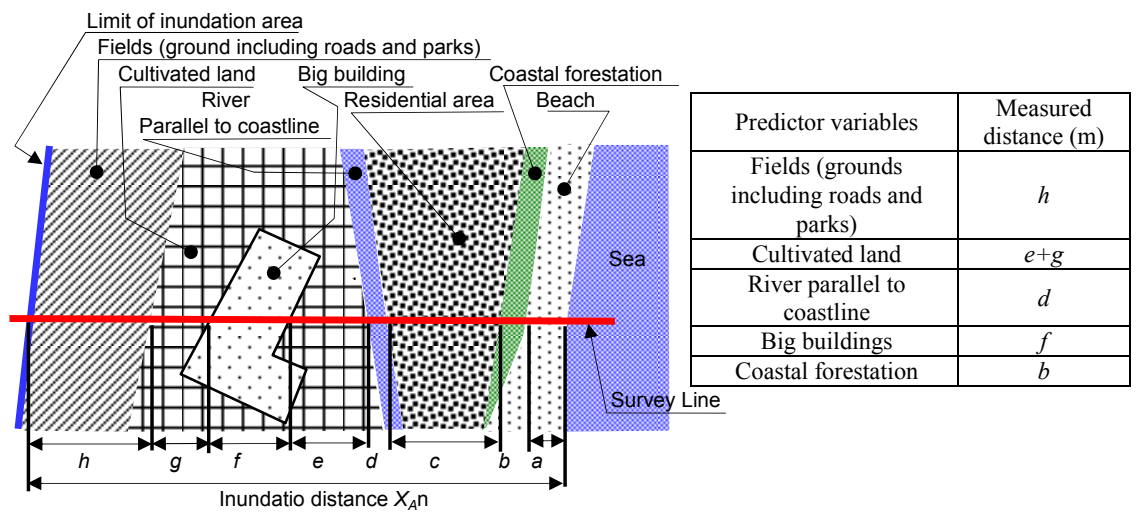

Figure 7: Example of method for measuring predictor variables.

\subsection{Risk analysis for future tsunami}

We conducted a risk analysis on the inundation for a future tsunami caused by the Tokai, Tounankai, and Nankai type earthquake. We selected the coast of Iwata City in Shizuoka Prefecture facing the Pacific Ocean as the study area, as shown in Figure 8. A broad plain stretches out from coastline to inland, similar to the Sendai plain. It is estimated that a large earthquake will strike this area in the future, and the resulting tsunami will likely inundate towns along the coast. We divided this area into nine regions, each $3000 \mathrm{~m}$ long by $500 \mathrm{~m}$ wide, as shown in Figure 8. The component ratio of land use was surveyed using aerial photographs and a field survey. We then assessed the degree of risk for each region. 


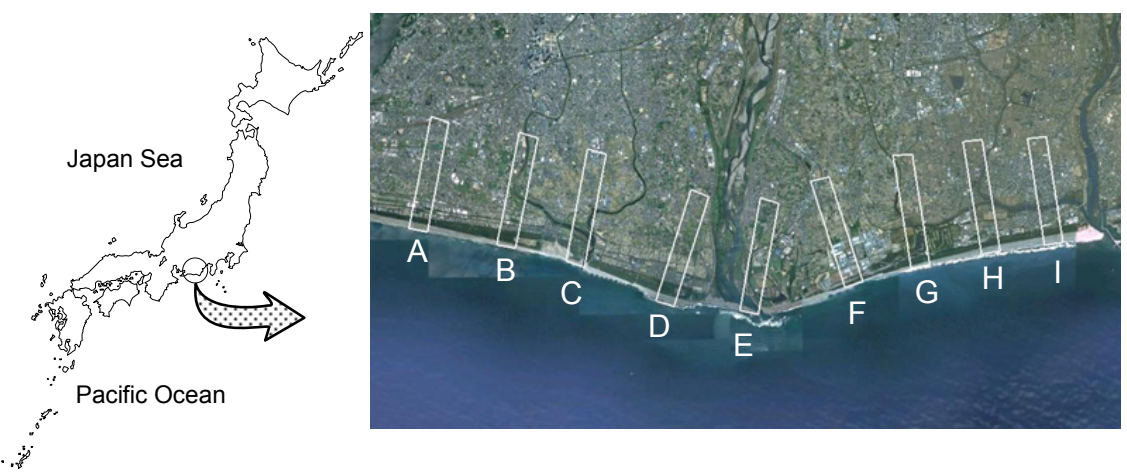

Figure 8: Test sites for tsunami risk analysis (Iwata City in Shizuoka Prefecture).

\section{Results of analysis}

\subsection{Factors that promote inundation}

The objective variable and predictor variables were measured using aerial photographs and survey results of the inundation area [4]. Table 1 shows the data (predictor variables) input into the neural network. Figure 9 shows the calculated values using the neural network compared with the actual values (i.e. teaching data) $\mathrm{X}_{\mathrm{A}}$ on the inundation distance from the coastline. As shown in Figure 9, the calculated values $X_{E}$ are almost equal to the actual values, within $\pm 3 \%$ error. The neural network estimated the inundation distance very well. Figure 10 shows the degree of importance of the predictor variables against the objective variable (inundation distance) based on the calculations using the neural network. As shown in Figure 10, the inundation was promoted by the ground (including cultivated land), roads, parks and rivers perpendicular to the coastline. On the other hand, the inundation was inhibited by rivers parallel to the coastline, lakes and ponds, coastal forestation and beaches. In addition, although it is considered that the inundation distance strongly depends on wave height, it had a low degree of importance in our network because we considered that there was little difference in wave height along the survey lines.

\subsection{Risk analysis for a future tsunami}

Table 2 shows the component ratio of land use in the nine selected regions. Table 3 shows the results of risk analysis based on Figure 10. As shown in Table 3, the degree of tsunami risk differs among neighboring regions. Measures to reduce the damage caused by a tsunami could include management of coastal forestation, creation of embankments, and construction of rivers (or canals) parallel to the coastline for irrigation of fields for common use. We also recommend that the foundations of arterial roads parallel to the coastline be made higher. 
Table 1: Measured values for predictor variables.

\begin{tabular}{|c|c|c|c|c|c|c|c|c|c|c|}
\hline $\begin{array}{l}\text { Survey } \\
\text { line } \\
\text { No. }\end{array}$ & $\begin{array}{c}\text { Beach } \\
\text { (m) }\end{array}$ & $\begin{array}{c}\text { Coastal } \\
\text { forestation } \\
(\mathrm{m})\end{array}$ & $\begin{array}{l}\text { Field } \\
\text { (m) }\end{array}$ & $\begin{array}{l}\text { Cultiv- } \\
\text { ated } \\
\text { land }(\mathrm{m})\end{array}$ & $\begin{array}{c}\text { Reside- } \\
\text { ntial } \\
\text { area } \\
(\mathrm{m})\end{array}$ & $\begin{array}{c}\text { Big } \\
\text { buildings } \\
(\mathrm{m})\end{array}$ & $\begin{array}{l}\text { Rivers } \\
\text { parallel to } \\
\text { coastline } \\
\text { (m) }\end{array}$ & $\begin{array}{c}\text { Rivers } \\
\text { perpend- } \\
\text { icular } \\
\text { to coast } \\
\text { line }(\mathrm{m}) \\
\end{array}$ & $\begin{array}{c}\text { Lakes } \\
\text { and } \\
\text { ponds } \\
\text { (m) }\end{array}$ & $\begin{array}{l}\text { Wave } \\
\text { height } \\
\text { (m) }\end{array}$ \\
\hline 1 & 65 & 305 & 2816 & 0 & 0 & 696 & 0 & 0 & 0 & 9.0 \\
\hline 2 & 150 & 70 & 2144 & 0 & 110 & 1050 & 0 & 0 & 369 & 8.8 \\
\hline 3 & 169 & 0 & 2693 & 0 & 300 & 426 & 0 & 0 & 387 & 8.6 \\
\hline 4 & 262 & 0 & 2367 & 150 & 655 & 512 & 0 & 0 & 93 & 8.4 \\
\hline 5 & 258 & 0 & 2006 & 25 & 1339 & 281 & 0 & 0 & 122 & 8.8 \\
\hline 6 & 63 & 0 & 1008 & 0 & 1878 & 90 & 0 & 1465 & 0 & 8.7 \\
\hline 7 & 185 & 225 & 1475 & 0 & 0 & 0 & 0 & 3117 & 0 & 8.6 \\
\hline 8 & 185 & 220 & 169 & 2032 & 835 & 231 & 46 & 0 & 0 & 8.8 \\
\hline 9 & 153 & 254 & 192 & 2029 & 884 & 105 & 38 & 0 & 0 & 12.6 \\
\hline 10 & 166 & 197 & 672 & 1253 & 321 & 198 & 37 & 0 & 0 & 7.1 \\
\hline 11 & 157 & 353 & 185 & 2152 & 0 & 0 & 43 & 0 & 0 & 10 \\
\hline 12 & 147 & 436 & 182 & 1704 & 339 & 0 & 56 & 0 & 0 & 7.5 \\
\hline 13 & 170 & 311 & 319 & 2245 & 155 & 0 & 46 & 0 & 0 & 7.3 \\
\hline 14 & 174 & 285 & 300 & 2518 & 203 & 0 & 26 & 0 & 0 & 9.0 \\
\hline 15 & 163 & 386 & 271 & 2376 & 769 & 45 & 29 & 0 & 0 & 10.2 \\
\hline 16 & 174 & 664 & 106 & 2939 & 174 & 0 & 26 & 0 & 0 & 12.1 \\
\hline 17 & 176 & 670 & 214 & 3035 & 0 & 0 & 24 & 0 & 0 & 13.8 \\
\hline 18 & 163 & 574 & 0 & 3115 & 0 & 0 & 22 & 0 & 228 & 14.3 \\
\hline 19 & 176 & 594 & 0 & 3204 & 120 & 0 & 22 & 0 & 0 & 11.5 \\
\hline 20 & 156 & 540 & 0 & 3271 & 0 & 0 & 23 & 0 & 0 & 5.4 \\
\hline 21 & 177 & 587 & 0 & 3132 & 0 & 0 & 23 & 0 & 145 & 5.4 \\
\hline 22 & 165 & 709 & 159 & 2462 & 0 & 238 & 23 & 0 & 287 & 6.1 \\
\hline 23 & 152 & 548 & 380 & 2589 & 76 & 120 & 21 & 0 & 0 & 6.1 \\
\hline
\end{tabular}


Table 1: Continued.

\begin{tabular}{|c|c|c|c|c|c|c|c|c|c|c|}
\hline $\begin{array}{l}\text { Survey } \\
\text { line } \\
\text { No. }\end{array}$ & $\begin{array}{c}\text { Beach } \\
\text { (m) }\end{array}$ & $\begin{array}{c}\text { Coastal } \\
\text { forestation } \\
\quad(\mathrm{m})\end{array}$ & $\begin{array}{l}\text { Field } \\
(\mathrm{m})\end{array}$ & $\begin{array}{l}\text { Cultiv- } \\
\text { ated } \\
\text { land } \\
(\mathrm{m})\end{array}$ & $\begin{array}{c}\text { Reside- } \\
\text { ntial } \\
\text { area } \\
(\mathrm{m})\end{array}$ & $\begin{array}{c}\text { Big } \\
\text { buildings } \\
\text { (m) }\end{array}$ & $\begin{array}{c}\text { Rivers } \\
\text { parallel to } \\
\text { coastline } \\
\text { (m) }\end{array}$ & $\begin{array}{c}\text { Rivers } \\
\text { perpend- } \\
\text { icular } \\
\text { to coast } \\
\text { line }(\mathrm{m})\end{array}$ & $\begin{array}{l}\text { Lakes } \\
\text { and } \\
\text { ponds } \\
\text { (m) }\end{array}$ & $\begin{array}{l}\text { Wave } \\
\text { height } \\
\text { (m) }\end{array}$ \\
\hline 24 & 160 & 559 & 155 & 2503 & 304 & 0 & 20 & 0 & 0 & 5.7 \\
\hline 25 & 175 & 665 & 0 & 2790 & 0 & 0 & 27 & 0 & 0 & 5.3 \\
\hline 26 & 241 & 297 & 368 & 2475 & 93 & 0 & 53 & 0 & 0 & 4.8 \\
\hline 27 & 248 & 51 & 222 & 2685 & 503 & 111 & 27 & 33 & 0 & 5.3 \\
\hline 28 & 206 & 63 & 66 & 100 & 1197 & 0 & 30 & 0 & 0 & 12.2 \\
\hline 29 & 197 & 87 & 163 & 2934 & 674 & 0 & 30 & 0 & 0 & 11.2 \\
\hline 30 & 200 & 488 & 154 & 2866 & 317 & 0 & 27 & 0 & 0 & 9.2 \\
\hline 31 & 127 & 422 & 0 & 3029 & 337 & 0 & 33 & 0 & 0 & 7.2 \\
\hline 32 & 114 & 614 & 0 & 2867 & 358 & 0 & 326 & 0 & 0 & 5.9 \\
\hline 33 & 97 & 599 & 120 & 2485 & 374 & 0 & 30 & 0 & 0 & 5.8 \\
\hline 34 & 100 & 603 & 0 & 2956 & 0 & 0 & 29 & 0 & 0 & 5.6 \\
\hline 35 & 89 & 253 & 289 & 2058 & 0 & 0 & 0 & 951 & 0 & 5.3 \\
\hline 36 & 82 & 641 & 110 & 2440 & 281 & 0 & 46 & 0 & 0 & 5.0 \\
\hline 37 & 64 & 637 & 295 & 2283 & 425 & 0 & 44 & 0 & 0 & 4.9 \\
\hline 38 & 58 & 661 & 136 & 2725 & 229 & 0 & 40 & 0 & 0 & 5.0 \\
\hline 39 & 62 & 615 & 0 & 2997 & 0 & 0 & 44 & 0 & 0 & 5.2 \\
\hline 40 & 49 & 622 & 127 & 2417 & 410 & 0 & 46 & 0 & 0 & 5.1 \\
\hline 41 & 42 & 600 & 289 & 2432 & 184 & 0 & 46 & 0 & 0 & 5.3 \\
\hline 42 & 42 & 613 & 109 & 2108 & 296 & 0 & 43 & 0 & 0 & 6.3 \\
\hline 43 & 57 & 470 & 245 & 2292 & 141 & 0 & 91 & 0 & 0 & 16.1 \\
\hline 44 & 57 & 344 & 176 & 2089 & 346 & 0 & 48 & 0 & 189 & 11.9 \\
\hline 45 & 59 & 319 & 274 & 2777 & 72 & 0 & 30 & 0 & 185 & 8.0 \\
\hline 46 & 55 & 331 & 191 & 1831 & 670 & 0 & 225 & 0 & 0 & 4.6 \\
\hline
\end{tabular}


Table 1: Continued.

\begin{tabular}{|c|c|c|c|c|c|c|c|c|c|c|}
\hline $\begin{array}{c}\text { Survey } \\
\text { line } \\
\text { No. }\end{array}$ & $\begin{array}{c}\text { Beach } \\
(\mathrm{m})\end{array}$ & $\begin{array}{c}\text { Coastal } \\
\text { forestation } \\
(\mathrm{m})\end{array}$ & $\begin{array}{c}\text { Field } \\
(\mathrm{m})\end{array}$ & $\begin{array}{c}\text { Cultiv- } \\
\text { ated } \\
\text { land }(\mathrm{m})\end{array}$ & $\begin{array}{c}\text { Reside- } \\
\text { ntial }\end{array}$ & $\begin{array}{c}\text { Big } \\
\text { buildings } \\
(\mathrm{m})\end{array}$ & $\begin{array}{c}\text { Rivers } \\
\text { parallel to } \\
\text { coastline } \\
(\mathrm{m})\end{array}$ & $\begin{array}{c}\text { Rivers } \\
\text { perpend- } \\
\text { icular } \\
\text { to coast } \\
\text { line }(\mathrm{m})\end{array}$ & $\begin{array}{c}\text { Lakes } \\
\text { and } \\
\text { ponds } \\
(\mathrm{m})\end{array}$ & $\begin{array}{c}\text { Wave } \\
\text { height } \\
(\mathrm{m})\end{array}$ \\
\hline 47 & 78 & 285 & 272 & 2618 & 486 & 0 & 238 & 0 & 0 & 3.8 \\
\hline 48 & 75 & 307 & 222 & 3509 & 187 & 0 & 241 & 1338 & 0 & 4.1 \\
\hline 49 & 101 & 439 & 398 & 2265 & 0 & 0 & 237 & 117 & 0 & 4.3 \\
\hline 50 & 118 & 145 & 314 & 3112 & 0 & 0 & 303 & 256 & 0 & 4.5 \\
\hline 51 & 106 & 50 & 442 & 1808 & 556 & 0 & 344 & 278 & 0 & 4.7 \\
\hline 52 & 120 & 55 & 765 & 916 & 294 & 0 & 400 & 839 & 0 & 5.1 \\
\hline 53 & 184 & 0 & 0 & 1348 & 0 & 0 & 402 & 1238 & 0 & 5.6 \\
\hline 54 & 298 & 0 & 310 & 1383 & 0 & 74 & 0 & 1283 & 0 & 6.8 \\
\hline 55 & 0 & 0 & 0 & 1956 & 1020 & 0 & 0 & 776 & 0 & 8.5 \\
\hline 56 & 0 & 0 & 168 & 1986 & 1041 & 0 & 34 & 0 & 755 & 9.3 \\
\hline 57 & 0 & 50 & 222 & 2171 & 754 & 0 & 43 & 0 & 180 & 8.4 \\
\hline 58 & 287 & 0 & 273 & 2441 & 624 & 0 & 36 & 0 & 187 & 7.5 \\
\hline 59 & 226 & 87 & 342 & 1977 & 715 & 91 & 33 & 0 & 218 & 10.2 \\
\hline 60 & 203 & 121 & 0 & 2433 & 338 & 0 & 48 & 0 & 276 & 8.3 \\
\hline
\end{tabular}

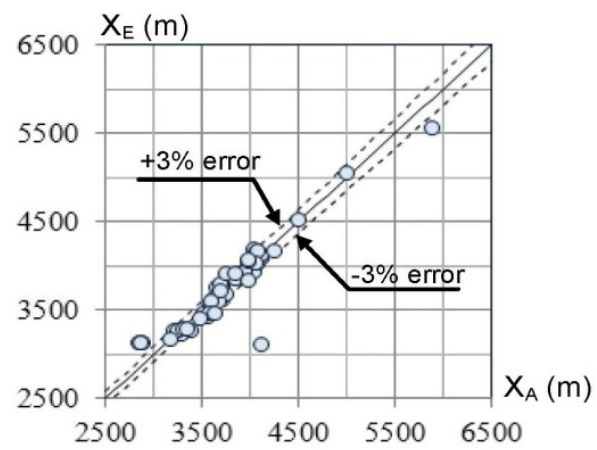

Figure 9: Comparison of estimated and actual values. 


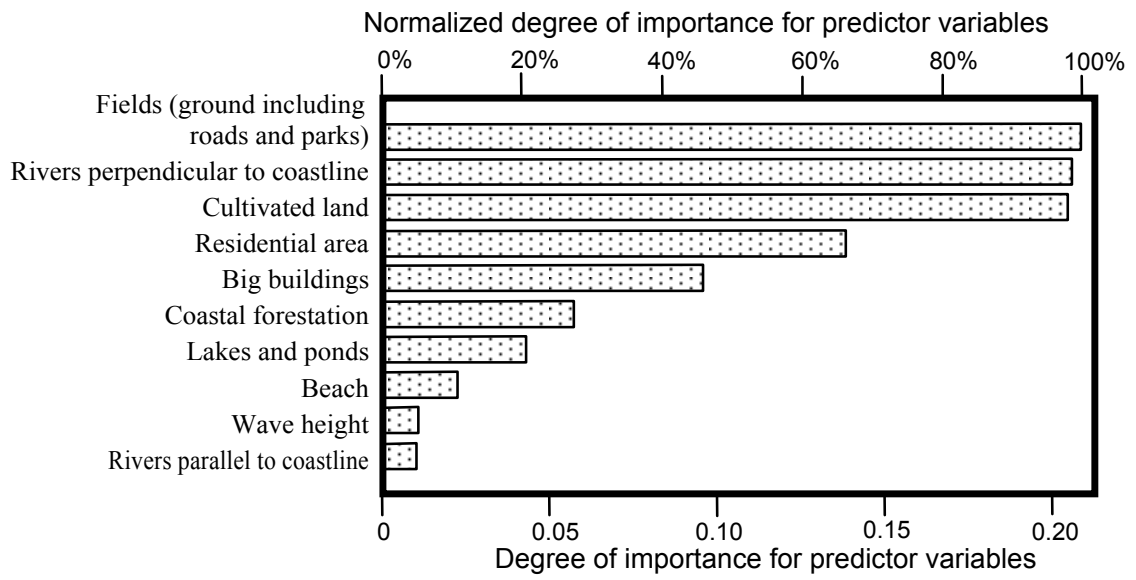

Figure 10: Factors affecting inundation area.

Table 2: Component ratios of land use in selected regions.

\begin{tabular}{|c|c|c|c|c|c|c|c|c|c|}
\hline \multirow{2}{*}{ Predictor variables } & \multicolumn{9}{|c|}{ Survey Area (\%) } \\
\hline & $\mathrm{A}$ & B & $\mathrm{C}$ & $\mathrm{D}$ & $\mathrm{E}$ & $\mathrm{F}$ & $\mathrm{G}$ & $\mathrm{H}$ & $\mathrm{I}$ \\
\hline Beach & 5.8 & 3.5 & 5.7 & 8.6 & 5.4 & - & 3.0 & 3.5 & 7.9 \\
\hline Coastal forestation & 8.0 & 13.2 & 17.5 & 10.8 & 1.8 & 5.5 & 20.0 & 14.1 & 6.4 \\
\hline $\begin{array}{l}\text { Fields (ground including } \\
\text { roads and parks) } \\
\text { /Cultivated land }\end{array}$ & 54.7 & 53.7 & 52.1 & 56.6 & 68.5 & 75.9 & 57.4 & 52.3 & 33.2 \\
\hline Residential area & 28.4 & 12.2 & 9.3 & 23.2 & 8.8 & 7.6 & 8.0 & 12.6 & 46.0 \\
\hline Big buildings & 3.6 & 4.9 & 4.7 & 0.8 & 3.3 & 11.0 & - & 5.6 & 3.6 \\
\hline $\begin{array}{l}\text { Rivers parallel to } \\
\text { coastline }\end{array}$ & - & - & - & - & - & - & 2.1 & 1.5 & 2.9 \\
\hline $\begin{array}{l}\text { Rivers perpendicular to } \\
\text { coastline }\end{array}$ & - & 12.5 & 10.6 & - & 12.1 & - & 4.3 & 10.4 & - \\
\hline Lakes and ponds & - & - & - & - & - & - & 5.2 & - & - \\
\hline
\end{tabular}

\section{Conclusion}

In the present study, we attempted to clarify the factors that promoted (predictor variables) inundation in coastal regions from the tsunami after the Great East Japan Earthquake on March 11, 2011. Using risk analysis of these factors, we also estimated the degree of risk for tsunami in Iwata City, Shizuoka Prefecture, and we proposed measures to reduce potential damage from a tsunami. The main results are summarized as follows:

- Using a neural network for the analysis, the predictor variables to reduce the inundation distance are rivers parallel to the coastline, lakes or ponds, coastal forestation, large buildings such as factories and warehouses, and beaches. Moreover, the risk analysis for tsunami in 
the case of Iwata City in Shizuoka Prefecture was performed using the factors that inhibit inundation, and the judgments on safety were made.

- For areas where earthquakes may occur in the future, we propose managing coastal forestation, creating embankments, and constructing rivers (or canals) parallel to the coastline as measures to reduce tsunami damage.

Table 3: Result of risk analysis for Iwata City in Shizuoka Prefecture.

\begin{tabular}{|c|c|c|c|c|c|c|c|c|c|}
\hline \multirow{2}{*}{ Predictor variables } & \multicolumn{9}{|c|}{ Survey Area } \\
\hline & A & B & $\mathrm{C}$ & $\mathrm{D}$ & $\mathrm{E}$ & $\mathrm{F}$ & $\mathrm{G}$ & $\mathrm{H}$ & I \\
\hline $\begin{array}{l}\text { Fields (ground including } \\
\text { roads and parks)/ } \\
\text { Cultivated land } \\
\end{array}$ & IV & IV & IV & IV & $\mathrm{V}$ & $\mathrm{V}$ & IV & IV & IV \\
\hline $\begin{array}{l}\text { Rivers perpendicular to } \\
\text { coastline }\end{array}$ & & III & III & & III & & III & III & \\
\hline Big buildings & & & & & & II & & & \\
\hline Coastal forestation & & II & II & II & & & II & II & \\
\hline Lakes and ponds & & & & & & & I & & \\
\hline Beach & II & & II & II & II & & & & II \\
\hline $\begin{array}{l}\text { Rivers parallel to } \\
\text { coastline }\end{array}$ & & & & & & & I & I & I \\
\hline Residential area & 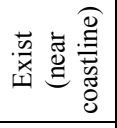 & 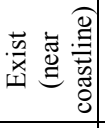 & & 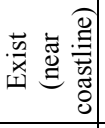 & & & & 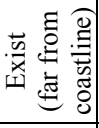 & 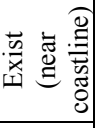 \\
\hline Judgment on Safety & $x$ & $x$ & O & $x$ & $\Delta$ & O & O & $\Delta$ & $x$ \\
\hline
\end{tabular}

I: It can be expected to reduce damage greatly.

II: It can be expected to reduce damage.

III: Not exceeding 30\% land use is not expected to reduce damage.

IV: $30-60 \%$ land use is not expected to reduce damage.

$\mathrm{V}$ : Exceeding $60 \%$ land use is not expected to reduce damage.

: The area has large risk for loss of life due to tsunami-induced current.

: The area has low risk for loss of life, although there is inundation by the tsunami.

: The area has little risk for loss of life because of reduced inundation.

\section{References}

[1] Reconstruction Agency: Situation of damage for every prefecture, http://www.npa.go.jp/archive/keibi/biki/higaijokyo.pdf (2014.2.6).

[2] Coastal Engineering Committee of JSCE (The 2011 Tohoku Earthquake Tsunami Joint Survey Group): The 2011 off the Pacific coast of Tsunami Information, http://www.coastal.jp/ttjt/ (2014.2.6).

[3] Cabinet Office, Government of Japan: White paper, http://www.bousai.go. $\mathrm{jp} / \mathrm{kaigirep} / \mathrm{hakusho} / \mathrm{h} 23 /$ bousai2011/html/zu/zu004.htm (2014.2.6).

[4] Geospatial Information Authority of Japan: General inundation area maps for the 2011 off the Pacific coast of Tohoku Earthquake Tsunami. http://www.gsi.go.jp/ (2014.2.6). 